\title{
ANDRZEJ SZEPTYCKI
}

Uniwersytet Warszawski

\section{Tożsamość międzynarodowa: zarys problematyki}

\section{International identity: An outline of the problem}

The article is devoted to identity issues in international relations. The author describes the main theoretical approaches to the issue of identity (the Copenhagen school, the constructivist theory of international relations, the contribution of Polish researchers) and discusses the specificity of the identities of the main participants in international relations (states, nations, regions, sub-state entities). Then he proposes his own concept of international identity and analyses its most important components (geography, history and culture), the behaviours of the entities that articulate it (political and cultural elites, society) and the influence of the external environment that co-shapes it. Finally, he applies the aforementioned concept to the Polish case and presents the main components of the Polish identity, as well as past and present political activities aimed at forming it.

Keywords: international identity, Copenhagen school, constructivist theory of international relations, identity of states, identity of nations, identity of the European Union, identity of Poland

Słowa kluczowe: tożsamość międzynarodowa, szkoła kopenhaska, konstruktywistyczna teoria stosunków międzynarodowych, tożsamość państw, tożsamość narodów, tożsamość Unii Europejskiej, tożsamość Polski

W filozofii tożsamość jest jedną z najstarszych kategorii metafizycznych. Pojęcie to rozumiano dwojako, wyrażając je po łacinie słowami ipse i idem, które można tłumaczyć odpowiednio jako 'tożsame' (,A jest A”) i 'identyczne' (,Oto dwaj identyczni bliźniacy, ale nie tożsami”)². Problemem tożsamości zajmowali się m.in. Parmenides, Platon, Arystoteles, św. Tomasz, Immanuel Kant, Georg Hegel, Martin Heidegger i ponowocześni filozofowie XX w. ${ }^{3}$ Na gruncie

1 M. Heidegger, Identyczność i różnica, Warszawa 2010, s. 21.

2 B. Skarga, Tożsamość i różnica. Eseje metafizyczne, Kraków 2009, s. 233.

3 J. Grzybowski, Byt, Tożsamość, Naród. Próba wyjaśnienia formuly „tożsamość narodowa" w perspektywie metafizyki, Kęty 2012, s. 26. 
socjologii można ją pojmować ,jako »istotę« człowieka bądź takie jego ukształtowanie, w którym realizuje się sens jego egzystencji” (perspektywa normatywna), lub jako próbę całościowego opisu struktury tożsamości, pewnego jej sektora, powstania lub dynamiki jej przemian (perspektywa deskryptywna) ${ }^{4}$. Ważnym przedmiotem analizy filozoficznej i socjologicznej stały się wzajemne relacje pomiędzy tożsamością jednostkową i zbiorową ${ }^{5}$. Wypracowano rozmaite narzędzia służące analizie tożsamości, takie jak badania opinii publicznej, analiza dyskursu i analiza treści (content analysis) ${ }^{6}$. Problematykę tożsamości podejmowano również na gruncie innych nauk społecznych: historii, językoznawstwa, geografii czy studiów postkolonialnych?

Celem niniejszego artykułu jest przedstawienie pojęcia tożsamości na gruncie stosunków międzynarodowych, rozumianych zarówno jako pewien obszar życia społecznego, jak i nauka. W tym celu dokonano w tekście przeglądu najważniejszych koncepcji teoretycznych dotyczących tożsamości na gruncie nauki o stosunkach międzynarodowych, omówiono - w oparciu o dorobek nauk społecznych - tożsamość wybranych uczestników stosunków międzynarodowych, zaproponowano zarys autorskiej koncepcji tożsamości międzynarodowej i wreszcie podjęto próbę zastosowania jej w odniesieniu do przypadku Polski.

\section{Tożsamość na gruncie teorii stosunków międzynarodowych}

W klasycznych teoriach stosunków międzynarodowych problematyka tożsamości była właściwie nieobecna, a w najlepszym wypadku jej rolę marginalizowano. Scjentystyczne dążenie do racjonalizacji zagadnień polityki i bezpieczeństwa prowadziło do ignorowania kwestii niewygodnych czy też trudnych pod względem badawczym ${ }^{8}$.

Wzrost zainteresowania problematyką tożsamości w stosunkach międzynarodowych związany był ściśle z końcem zimnej wojny, gdy w naukach

4 Z. Bokszański, Tożsamości zbiorowe, Warszawa 2005, s. 31-33.

5 Por. J.-C. Deschamps, T. Devos, Regarding the relationship between social identity and personal identity, [w:] Social identity. International perspectives, ed. S. Worchel i in., London-Thousand Oaks-New Delhi 1998, s. 1-12.

6 Measuring identity. A guide for social scientists, ed. R. Abdelal i in., Cambridge 2009, zwłaszcza s. 72-109.

7 Szerzej na temat historii pojęcia tożsamości zob. np. G. Izenberg, Identity. The necessity of a modern idea, Philadelphia 2016.

8 M.C. Williams, Identity and the politics of security, „European Journal of International Relations" 1998, vol. 4, No. 2, s. 204-225. 
społecznych dokonał się zwrot kulturowy9 . Zajęło się nią w pierwszej kolejności kilku wybitnych, a przynajmniej rozpoznawalnych badaczy, niekoniecznie bezpośrednio związanych z nauką o stosunkach międzynarodowych. Amerykański politolog Samuel Huntington sformułował tezę o zderzeniu cywilizacji, twierdząc, że to „kultura i tożsamość kulturowa, będąca w szerokim pojęciu tożsamością cywilizacji, kształtują wzorce spójności, dezintegracji i konfliktu w świecie, jaki nastał po zimnej wojnie" ${ }^{10}$. W związku z tym ,konflikty między grupami należącymi do różnych cywilizacji zajmują [...] centralne miejsce w polityce światowej" ${ }^{11}$. Również teoretyk polityki Benjamin Barber uznał, że problemy tożsamościowe są zasadniczym czynnikiem destabilizującym współczesny świat. W jego opinii linie podziału nie przebiegały jednak między cywilizacjami, a pomiędzy konsumpcyjnym, kapitalistycznym McŚwiatem i fundamentalistycznym, plemiennym Dżihadem (którego nie utożsamiał bynajmniej z fundamentalizmem islamskim). Pierwszy ma na celu maksymalizację zysku, drugi zaś - ochronę swojej tożsamości. Oba zagrażają demokracji i będącemu jej ostoją państwu narodowemu ${ }^{12}$. Manuel Castells, socjolog hiszpańskiego pochodzenia, definiował tożsamość jako ,proces konstruowania sensu na podstawie pewnego atrybutu kulturowego lub powiązanego zbioru atrybutów kulturowych, któremu/którym przyznaje się pierwszeństwo przed innymi źródłami sensu" ${ }^{13}$. Wskazywał na rosnące znaczenie aktorów społecznych, którzy w oparciu o łączącą ich tożsamość oporu (wynikającą z doświadczanej dyskryminacji) lub tożsamość projektu (opartą o wizję lepszego świata) chcą podważyć istniejący porządek. Koncepcje tych badaczy (zwłaszcza Huntingtona i Barbera) opierały się na pewnych uproszczeniach, dążąc do sprowadzenia problematyki tożsamości do jednego podstawowego konfliktu, przez co przyczyniły się do jej popularyzacji.

$\mathrm{Na}$ gruncie nauki o stosunkach międzynarodowych refleksję na temat znaczenia tożsamości podjęła szkoła kopenhaska. Jej przedstawiciele uważali, że po zakończeniu zimnej wojny tożsamość etniczno-narodowa stała się głównym zagrożeniem dla bezpieczeństwa europejskiego. W zachodniej części kontynentu najważniejszym problemem była w tym kontekście

9 H. Schreiber, G. Michałowska, Wprowadzenie. Zwrot kulturowy w stosunkach międzynarodowych, [w:] Kultura w stosunkach międzynarodowych, red. H. Schreiber, G. Michałowska, Warszawa 2013, s. 7-8.

10 S. Huntington, Zderzenie cywilizacji i nowy kształt ładu światowego, Warszawa 1997, s. 24.

11 Tamże, s. 179-180.

12 B.R. Barber, Dżihad kontra McŚwiat, Warszawa 2007.

13 M. Castells, Wiek informacji: ekonomia, społeczeństwo i kultura, t. 2: Siła tożsamości, Warszawa 2008, s. 23-24. 
imigracja, w Europie Wschodniej natomiast - rozpad Związku Radzieckiego według linii etnicznych ${ }^{14}$. Szkoła kopenhaska upowszechniła pojęcie bezpieczeństwa społecznego. Definiowano je jako zdolność społeczeństwa do zachowania - mimo zmieniających się warunków, rzeczywistych i potencjalnych zagrożeń - swojego specyficznego charakteru, tradycyjnych wzorców w sferze języka, kultury, skojarzeń, tożsamości oraz praktyk narodowych czy religijnych, przy jednoczesnym uwzględnieniu tych koniecznych zmian, które zostaną uznane za dopuszczalne ${ }^{15}$. Bezpieczeństwo społeczne zostało uznane za jeden z pięciu obszarów bezpieczeństwa, obok politycznego, wojskowego, gospodarczego i ekologicznego ${ }^{16}$. Szkoła kopenhaska wniosła wymierny wkład w wypracowanie nowego, szerokiego pojęcia bezpieczeństwa i wskazała na jego bezpośredni związek z kwestiami tożsamościowymi; nie podjęła jednak próby szerszego zdefiniowania pojęcia tożsamości na płaszczyźnie teoretycznej ${ }^{17}$.

Więcej uwagi poświęcili mu badacze wpisujący się w nurt konstruktywistyczny - podejście powstałe w latach osiemdziesiątych XX w. w opozycji do paradygmatu racjonalistycznego, będącego syntezą neoliberalizmu i neorealizmu ${ }^{18}$. Tożsamość, jak pisze Richard Lebow, jest dla konstruktywistów pojęciem centralnym, tak jak potęga dla realistów i bogactwo dla liberałów ${ }^{19}$. Konstruktywiści wskazywali na słabość tych wcześniejszych podejść, zarzucając im, że nie wyjaśniają genezy interesów i tożsamości poszczególnych państw ani ich ewolucji ${ }^{20}$. Konstruktywizm wprowadził do nauki o stosunkach międzynarodowych przekonanie o społecznym pochodzeniu rzeczywistości. Według jego zwolenników państwa istnieją jedynie dzięki temu, że ludzie zbiorowo wierzą $\mathrm{w}$ ich istnienie i postępują zgodnie $\mathrm{z}$ tą wiarą ${ }^{21}$.

14 Identity, migration and the new security agenda in Europe, ed. O. Wæver i in., Basingstoke-New York 1993.

15 Tamże, s. 23.

16 B. Buzan, O. Wæver, J. de Wilde, Security. A new framework for analysis, Boulder 1998, s. 119.

17 Krytyczna analiza poglądów szkoły kopenhaskiej: B. McSweeney, Security, identity and interests. A sociology of international relations, Cambridge 1999.

18 Por. A. Wendt, Anarchy is what states make of it. The social construction of power politics, „International Organization” 1992, vol. 46, No. 2, s. 391-392.

19 R.N. Lebow, The politics and ethics of identity. In search of ourselves, Cambridge 2012, s. 1.

20 J.G. Ruggie, What makes the world hang together? Neo-utilitarianism and the social constructivist challenge, „International Organization” 1998, vol. 52, No. 4, s. 863.

21 R. Jackson, G. Sørensen, Wprowadzenie do stosunków międzynarodowych. Teorie i kierunki badawcze, Kraków 2006, s. 270. 
Tożsamość nie jest czynnikiem egzogenicznym, jak utrzymują racjonaliści, ale powstaje w wyniku interakcji między państwami. Tożsamości są zmienne w czasie, warunkują współpracę i rywalizację państw. Każde z nich może mieć jedną lub kilka tożsamości ${ }^{22}$. Konstruktywizm miał fundamentalne znaczenie dla zrozumienia kwestii tożsamości w stosunkach międzynarodowych, choć jego wykorzystanie utrudniało wewnętrzne zróżnicowanie tej szkoły ${ }^{23}$ (konstruktywizm systemowy Alexandra Wendta ${ }^{24}$, konstruktywizm kulturowy Friedricha Kratochwila ${ }^{25}$, konstruktywizm „miękkiego racjonalizmu” Petera Katzensteina ${ }^{26}$ ).

Na gruncie polskiej nauki o stosunkach międzynarodowych tożsamością zajmowali się przede wszystkim Józef Kukułka i Stanisław Bieleń. Pierwszy z nich wskazywał na wzrost znaczenia tożsamości we współczesnych stosunkach międzynarodowych. Utożsamiał to pojęcie przede wszystkim z tożsamością narodowo-państwową ${ }^{27}$, uznając jej ochronę za jeden z egzystencjalnych celów i interesów państwa ${ }^{28}$. Według Bielenia natomiast „tożsamość jest kategorią mentalną, która przypisuje danemu aktorowi, jak winien on myśleć, odczuwać i zachowywać się w określonych sytuacjach, w kontekście innych aktorów. [...] Tożsamość międzynarodową państwa warunkują rozmaite czynniki, zwłaszcza geograficzne, historyczne i demograficzne, ekonomiczne i wojskowe, a także kulturowe, ideologiczne i psychologiczne"29. Refleksje obu autorów należy uznać za słuszne, odnotowując zarazem, że wymagają one uszczegółowienia i aktualizacji.

22 J. Czaputowicz, Teorie stosunków międzynarodowych. Krytyka i systematyzacja, Warszawa 2007, s. 303-307. Krytyczna ocena koncepcji tożsamości na gruncie konstruktywizmu strukturalnego: M. Zehfuss, Constructivism and identity. A dangerous liaison, „European Journal of International Relations” 2001, vol. 7, issue 3, s. 315-348.

23 J. Czaputowicz, Teorie..., s. 303-304.

24 A. Wendt, Spoleczna teoria stosunków międzynarodowych, Warszawa 2008.

25 The return of culture and identity in IR theory, ed. Y. Lapid, F.V. Kratochwil, Boulder 1996.

26 The culture of national security. Norms and identity in world politics, ed. P.J. Katzenstein, New York 1996.

27 J. Kukułka, Pojmowanie i istota tożsamości narodowej pod koniec XX wieku, [w:] Nowa tożsamość Niemiec i Rosji w stosunkach międzynarodowych, red. S. Bieleń, W. M. Góralski, Warszawa 1999, s. 11-15.

28 Tenże, Zaspokajanie potrzeb i rozwiązywanie konfliktów w stosunkach międzynarodowych, [w:] Stosunki międzynarodowe. Geneza, struktura, dynamika, red. E. Haliżak, R. Kuźniar, Warszawa 2006, s. 253.

29 S. Bieleń, Tożsamość $i$ interesy narodowe $w$ procesach identyfikacji międzynarodowej państw, [w:] Porządek międzynarodowy u progu XXI wieku, red. R. Kuźniar, Warszawa 2005, s. 521, 525. 


\section{Tożsamość wybranych uczestników stosunków międzynarodowych}

Na gruncie nauk społecznych toczono szeroką debatę na temat tożsamości różnych podmiotów zbiorowych, w tym tych, które tradycyjnie są przedmiotem zainteresowania nauki o stosunkach międzynarodowych.

„Tożsamość narodowa zbiorowości narodowej - stwierdza Antonina Kłoskowska - to jej zbiorowa samowiedza, jej samookreślenie, tworzenie obrazu własnego i cała zawartość, treść samowiedzy"30. Historycznie wyodrębniły się dwa główne modele tożsamości narodowej - kulturowy, właściwy narodom pozbawionym własnego państwa, oraz polityczny i państwowy, charakterystyczny dla narodów, które je mają ${ }^{31}$. Większość badaczy definiowała narody i ich tożsamość poprzez ich cechy konstytuujące. Do najważniejszych zaliczano podobieństwo fizyczne, język, religię, zwyczaje i przekonanie o wspólnym pochodzeniu ${ }^{32}$. Można przedstawić szerokie spektrum koncepcji tożsamości narodowej. Jedni autorzy traktują naród jako byt realny: etniczno-naturalistyczny (złączony więzami krwi) lub relacyjno-kulturowy (oparty na wspólnej kulturze, historii, języku, religii); to ostatnie podejście, obecnie stosowane częściej, reprezentowali m.in. Arnold Toynbee i Feliks Koneczny. Inni uważają naród za byt idealny: abstrakcyjną ideę opartą o pewne korelaty kulturowe, wyobrażoną wspólnotę (Benedict Anderson) czy też ideę polityczną (Ernest Gellner, Rogers Brubaker) ${ }^{33}$. $\mathrm{Na}$ gruncie nauk społecznych prowadzono badania dotyczące tożsamości (charakterów) poszczególnych narodów. Na uwagę zasługują tu zwłaszcza prace Deana Peabody, który przeanalizował m.in. narodowy charakter Anglików (zasada fair play, poszanowanie ciężkiej pracy, powściągliwość), Francuzów (racjonalizm, praworządność, indywidualizm), Niemców (wiara w siebie, poszanowanie hierarchii i współpracy) oraz Włochów (egoizm, troska o własny wizerunek, brak wzajemnego zaufania) ${ }^{34}$. Współcześnie szeroko zakrojone badania socjologiczne dotyczące tożsamości narodowej prowadziło Pew Research Centre. Dowodzą one, że w państwach wysokorozwiniętych (Europa, Stany Zjednoczone, Australia, Japonia) kluczowym

30 A. Kłoskowska, Kultury narodowe u korzeni, Warszawa 2005, s. 99.

31 T. Kuczur, Tożsamość kulturowa vs. tożsamość polityczna (przykład Niemiec i Francji) europejskie koncepcje samookreślenia się jednostki, [w:] Globalizacja - naród-jednostka. Zagadnienia tożsamości kulturowej, red. T. Kuczur, A. Błachnio, Toruń 2009, s. 129.

32 Z. Bokszański, Tożsamości..., s. 70.

33 J. Grzybowski, Byt..., s. 586-620.

34 D. Peabody, National characteristics, Cambridge 1985. 
jej elementem jest język ${ }^{35}$; w postkomunistycznych państwach Europy Środkowej i Wschodniej (inaczej niż w zachodniej części kontynentu) składają się na nią również religia, historia i miejsce urodzenia ${ }^{36}$.

Tożsamość państwa jest blisko związana z tożsamością narodową. O ile jednak w socjologii to naród czy też społeczeństwo (pewna wspólnota ludzka), a nie państwo (system instytucji), jest głównym przedmiotem zainteresowań badawczych, o tyle na gruncie nauki o stosunkach międzynarodowych jest odwrotnie. Potrzeba zatem autonomicznej refleksji na temat tożsamości państwa w stosunkach międzynarodowych. Konstruktywiści, którzy poświęcili tej problematyce najwięcej uwagi, definiują tożsamość jako pewien sposób konstruowania państwa (narodu), ideologię pozwalającą mu odróżnić się od innych. Tożsamość państw kształtują według nich kulturowe i instytucjonalne elementy ich globalnego czy wewnętrznego środowiska. Zależnie od okoliczności pierwszoplanową rolę odgrywają czynniki zewnętrzne lub wewnętrzne. Klęska w drugiej wojnie światowej zaowocowała zmianą tożsamości Niemiec i Japonii - odejściem od militaryzmu na rzecz kultury współpracy ${ }^{37}$. Tożsamość państwa wpływa na międzypaństwowe struktury normatywne, takie jak reżimy i wspólnoty międzynarodowe. Zmiany w ramach tożsamości danego państwa albo zmiany tożsamości państwa wpływają na jego interesy narodowe i politykę zagraniczną ${ }^{38}$. Badania porównawcze prowadzone w minionej dekadzie w oparciu o konstruktywistyczną teorię stosunków międzynarodowych pozwoliły na zidentyfikowanie głównych cech wybranych mocarstw, takich jak Niemcy (polityka odpowiedzialności), Chiny (rozwój), Indie (największa demokracja świata) czy Brazylia $(\text {,raj dla łajdaków”) })^{39}$.

35 B. Stokes, R. Stewart, What it takes to truly be 'one of us', 1.02.2017 [dostęp: 26.11.2018], dostępny w internecie: <https:/assets.pewresearch.org/wp-content/uploads/sites/2/2017/04/ 14094140/Pew-Research-Center-National-Identity-Report-FINAL-February-1-2017.pdf >.

36 A. Cooperman, S. Gardner, N. Sahgal i in., Eastern and western Europeans differ on importance of religion, views of minorities, and key social issues, 29.10.2018 [dostęp: 26.11.2018], dostępny w internecie: <http://www.pewforum.org/wp-content/uploads/ sites/7/2018/10/Eastern-Western-Europe-FOR-WEB-1.pdf $>$.

37 T.U. Berger, Norms, identity and national security in Germany and Japan, [w:] The culture of national security ..., s. 324, 330. Szerzej na temat tożsamości Japonii zob. L. Hagstrom, Identity change and foreign policy. Japan and its 'others', Abingdon-New York 2015.

38 R.L. Jepperson, A. Wendt, P.J. Katzenstein, Norms, identity and culture in national security, [w:] The culture of national security..., s. 58-62.

39 T. Hopf, B. B. Allan, Making identity count. Building a national identity database, Oxford 2016. 
Ważnym przedmiotem refleksji naukowej stała się tożsamość poszczególnych regionów świata, w szczególności Europy i/lub Unii Europejskiej ${ }^{40}$. Wspólna tożsamość jest warunkiem sine qua non rozwoju współpracy regionalnej ${ }^{41}$. Można przyjąć, że do głównych wyznaczników tożsamości europejskiej zaliczają się uwarunkowania przestrzenno-kulturowe, tradycje grecko-rzymskie, uniwersalistyczny dorobek chrześcijaństwa, tradycje państw narodowych, demokracja i społeczeństwo obywatelskie, rozwinięte formy współpracy paneuropejskiej i wreszcie kształtowanie się Unii

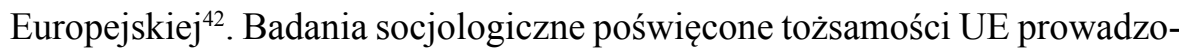
ne były m.in. w ramach realizowanego na zlecenie Komisji Europejskiej projektu Eurobarometr. Mieszkańcy wspólnoty postrzegają ją przede wszystkim jako strefę pokoju oraz obszar swobód rynku wewnętrznego (swobodnego przemieszczania się towarów, usług i ludzi). Około dwóch trzecich ankietowanych czuje się obywatelami Unii Europejskiej, choć dla większości z nich deklarowana tożsamość składa się z dwu komponentów - narodowego i dopiero w drugiej kolejności europejskiego ${ }^{43}$.

Rozwój tożsamości europejskiej napotyka na szereg problemów, chętnie analizowanych na gruncie naukowym, ale stanowiących istotne wyzwanie dla polityków. Po pierwsze, nie ma jasności, jakie są relacje między tożsamością europejską a tożsamością Unii Europejskiej. Zagadnienie to jest szczególnie istotne w przypadku państw, które z powodów geograficznych i historycznych zaliczane są do Europy, ale nie podzielają wartości europejskich (wartości UE), jak np. Białoruś ${ }^{44}$. Po drugie, trzeba wyjaśnić, jak ma się tożsamość państw członkowskich do tożsamości UE. Skoro te pierwsze cechuje większa żywotność, a na poziomie Unii nie ukształtowała się rzeczywista wspólnota polityczna (podobna do tych łączących obywateli poszczególnych państw wspólnoty), to zasadne jest pytanie, czy można mówić

40 Zob. np. The European Union's emerging international identity. Views from the global arena, ed. H. de Waele, J.-J. Kuipe, Leiden-Boston 2013; S. Bergbauer, Explaining European identity formation. Citizens' attachment from Maastricht Treaty to crisis, Cham 2017.

41 Por. E. Haliżak, Regionalizm w stosunkach międzynarodowych, [w:] Stosunki międzynarodowe..., s. 282.

42 K. Łastawski, Polskość w Europie. Polska tożsamość narodowa w jednoczacej się Europie, Warszawa 2004, s. 22-47.

43 European citizenship. Report, „Standard Eurobarometer” 2016, vol. 85, dostępny w internecie [dostęp: 26.11.2018]: <https://ec.europa.eu/commfrontoffice/publicopinion/index. $\mathrm{cfm} /$ ResultDoc/download/DocumentKy/75905> .

44 Por. S. White, V. Feklyunina, Identities and foreign policies in Russia, Ukraine and Belarus. The other Europes, Basingstoke-New York 2014, s. 163-186. 
o tożsamości europejskiej ${ }^{45}$. Po trzecie, wśród państw członkowskich nie ma zgody co do ważnych składowych wspólnego dziedzictwa, np. chrześcijaństwa czy znaczenia relacji transatlantyckich ${ }^{46}$. Po czwarte, istnieją obawy, że postępujące poszerzanie Unii Europejskiej może niekorzystnie wpływać na jej tożsamośćc ${ }^{47}$. Po piąte, nie ma zgody co do tego czy - przywołując terminologię Jana Zielonki - Unia Europejska ma być docelowo wspólnotą typu neowestfalskiego, $\mathrm{z}$ jedną dominującą tożsamością, czy też neośredniowiecznego, w ramach której wiele tożsamości mogłoby współistnieć obok siebie ${ }^{48}$. Przyjęcie drugiego z tych modeli z pewnością rozwiązałoby część wskazanych wyżej problemów.

Coraz większą rolę odgrywa w stosunkach międzynarodowych kwestia tożsamości regionalnej i lokalnej. W ślad za Markiem Szczepańskim można stwierdzić, że są to szczególne przypadki tożsamości społecznej i kulturowej opartej na tradycji regionalnej (lokalnej), odnoszonej do wyraźnie zdefiniowanego i delimitowanego terytorium, regionu (miejsca), jego specyficznych cech społecznych, kulturowych, gospodarczych czy nawet topograficznych, powodujących, że wyróżnia się spośród innych ${ }^{49}$. Niektórzy autorzy, szukając alternatywnych, bardziej nośnych synonimów tożsamości regionalnej (lokalnej), przywołują pojęcie genius loci (ducha miejsca) ${ }^{50} \mathrm{czy}$ ojczyzny prywatnej ${ }^{51}$.

Szczególne zainteresowanie budzą podmioty o wyrazistej tożsamości regionalnej czy lokalnej. Aspirują one do odgrywania samodzielnej roli w ramach państw, które wspóltworzą (np. bawarska Unia Chrześcijańsko-

45 Por. J. Habermas, Obywatelstwo a tożsamość narodowa. Rozważania nad przyszłościa Europy, Warszawa 1993; A.D. Smith, National identity and the idea of European unity, „International Affairs” 1992, vol. 68, No. 1, s. 55-76.

46 W kontekście rozważań o tożsamości Europy i Stanów Zjednoczonych należy przywołać dzieło Roberta Kagana Potęga i Raj, w którym autor dowodzi, że Amerykanie wolą przymus niż perswazję, a Europejczycy są nastawieni bardziej na pokojowe rozwiązania. R. Kagan, Potęga i Raj. Ameryka i Europa w nowym porzadku świata, Warszawa 2003.

47 D. Fuchs, H.-D. Klingemann, Eastward enlargement of the European Union and the identity of Europe, „West European Politics” 2002, vol. 25, No. 2, s. 19-54; D.D. Laitin, Culture and national identity. “The East” and European integration, „West European Politics" 2002, s. 55-80.

48 J. Zielonka, Europa jako imperium. Nowe spojrzenie na Unię Europejska, Warszawa 2007, s. 16.

49 M.S. Szczepański, Społeczności lokalne i regionalne a ład kontynentalny, [w:] Kręgi integracji i rodzaje tożsamości. Polska, Europa, świat, red. W. Wesołowski, J. Włodarek, Warszawa 2005, s. 128.

50 M. Pirveli, Duch miejsca a topofilia, [w:] Pamięć, przestrzeń, tożsamość, red. S. Kapralski, Warszawa 2010, s. 221.

51 S. Ossowski, O ojczyźnie i narodzie, Warszawa 1984, s. 35-40. 
-Społeczna (CSU), ściśle współpracująca z ogólnoniemiecką Unią Chrześcijańsko-Demokratyczną (CDU)), lub dążą do uzyskania niepodległości (Katalonia, potencjalnie Szkocja). Takie stanowisko ma wymierne konsekwencje międzynarodowe: secesja Katalonii czy Szkocji miałaby znaczący wpływ na pozycję międzynarodową Hiszpanii i Wielkiej Brytanii (czy raczej Anglii); byłaby też wyzwaniem dla UE z racji na konieczność ułożenia stosunków z nowo powstałymi państwami ${ }^{52}$.

W kontekście dotychczasowych rozważań istotne wydaje się pytanie o relacje pomiędzy tożsamością narodową i państwową a regionalną i lokalną. Większość badaczy zgadza się, że bezpośrednie więzi łączą jednostkę z ojczyzną prywatną ${ }^{53}$. Niektórzy wskazują jednak, że przywiązanie do ojczyzny prywatnej wzmacnia też przywiązanie do tej wielkiej ${ }^{54}$. Inni zwracają natomiast uwagę na fakt, że wobec współczesnych wyzwań (związanych m.in. z globalizacją) nowe formy tożsamości - m.in. terytorialnej - jako tożsamości oporu okazują się bardziej atrakcyjne niż dotychczasowe, w tym państwowa ${ }^{55}$.

\section{Autorska koncepcja tożsamości międzynarodowej}

Można przyjąć, że tożsamość międzynarodowa danej zbiorowości to zbiór symboli, norm i tradycji stanowiących o jej ciągłości w czasie i odrębności od innych grup, zarówno w sferze autopercepcji, jak i postrzegania przez innych - tych, którzy są przedmiotem jej szczególnej troski i wpływają na jej działania w środowisku międzynarodowym. Tożsamość warunkowana jest obiektywnie istniejącymi czynnikami o charakterze wewnętrznym, niemniej podlega ciągłej redefinicji przez aktorów społecznych wchodzących w skład danej zbiorowości, a pośrednio również przez jej zewnętrzne otoczenie.

Leszek Kołakowski wyraził przekonanie, że zarówno na poziomie jednostki, jak i zbiorowości tożsamość definiowana jest przez pięć zasadniczych cech: substancję bądź duszę (w przypadku zbiorowości jest to idea ducha narodowego), pamięć (pamięć historyczna), antycypację, ciało (terytorium),

52 Por. M. Keting, National and regional identities in Europe, „Contemporary European History" 2007, vol. 16, No. 3, s. 407-412.

53 M.S. Szczepański, Społeczności..., s. 123-124. Zob. też L. Dyczewski, Kultura lokalna a tożsamość, [w:] Region, tożsamość, edukacja, red. J. Nikitorowicz, D. Misiejuk, M. Sobecki, Białystok 2005, s. 35-40.

54 G. Labuda, Kaszubi i ich dzieje, Gdańsk 1996, s. 119.

55 M. Castells, Wiek..., s. 73, 382. Por. E. Wnuk-Lipiński, Świat międzyepoki. Globalizacja, demokracja, państwo narodowe, Kraków 2004, s. 234-235. 
umiejscowiony w czasie początek ${ }^{56}$. Barbara Szacka wskazuje na dwa zasadnicze wymiary tożsamości grupowej: wspólne terytorium i wspólne dzieje, które uznaje za najważniejsze elementy identyfikacyjne grupy ${ }^{57}$. Wobec tych propozycji oraz przywoływanej wcześniej literatury wydaje się, że w analizie tożsamości należy uwzględnić co najmniej trzy elementy: geografię, historię i kulturę. Znaczenie każdego z nich zależy od cech analizowanej grupy.

Człowiek jest istotą terytorialną ${ }^{58}$. Niemal od początku historii wspólnot ludzkich istniały uświęcone przez nie miejsca, symbolicznie łączące daną grupę - najpierw ognisko domowe, potem świątynie ${ }^{59}$.,Zagospodarowanie przestrzeni, architektura krajobrazu czy po prostu same w sobie formy architektoniczne stają się sposobem wyrażenia tożsamości [...] nie tylko tożsamości samego artysty, ale także tożsamości społecznej i kulturowej”"60. W wymiarze międzynarodowym istotny wpływ na tożsamość mają uwarunkowania geograficzne, gdyż stanowią o położeniu międzynarodowym, zwłaszcza w bezpośrednim sąsiedztwie. Powyższe tezy nie budzą wątpliwości w odniesieniu do wspólnot narodowych czy państwowych. Należy jednak zauważyć, że czynnik geograficzny jest również ważnym elementem tożsamości innych uczestników stosunków międzynarodowych, np. międzynarodowych organizacji i przedsiębiorstw czy związków wyznaniowych. Ich członkowie (wierni, akcjonariusze) wywodzą się bowiem z określonych regionów geograficznych, co wpływa na ich kulturę organizacyjną, a one same angażują się w określonych częściach świata ${ }^{61}$.

Wspólne dzieje są ściśle związane ze wspólnym terytorium, gdyż legitymizują w oczach grupy prawo do jego posiadania; im dłuższa jest jej bytność na danych ziemiach, tym bardziej uważa się za ich prawowitego właściciela ${ }^{62}$. Rola historii w definiowaniu tożsamości zbiorowej jest jednak daleko szersza. Historia jest podstawą składową pamięci zbiorowej, nawet jeśli ta ostatnia

56 L. Kołakowski, O tożsamości zbiorowej, [w:] tegoż, Moje stuszne poglądy na wszystko, Kraków 1999, s. 140-142.

57 B. Szacka, Czas przeszły, pamięć, mit, Warszawa 2006, s. 111.

58 Tamże, s. 111-112.

59 M. Maffesoli, Czas plemion. Schyłek indywidualizmu $w$ społeczeństwach ponowoczesnych, Warszawa 2008, s. 194.

60 H. Mamzer, Tożsamość w podróży. Wielokulturowość a ksztaltowanie tożsamości jednostki, Poznań 2003, s. 144.

61 Por. T. Łoś-Nowak, Państwowy poziom analizy w stosunkach międzynarodowych, [w:] Poziomy analizy stosunków międzynarodowych, t. 1, red. E. Haliżak, M. Pietraś, Warszawa 2013, s. 109.

62 B. Szacka, Czas..., s. 113. 
warunkowana jest społecznie ${ }^{63}$. „Pamięć zbiorowa na poziomie społecznym stwierdza Barbara Szacka - działa na rzecz tożsamości grupowej w trojaki sposób. 1. Po pierwsze, jako świadomość wspólnej przeszłości, to jest wspólnego trwania w czasie, budząca emocjonalny oddźwięk. [...] 2. Po drugie, jako przekaz wartości i wzorów zachowań. [...] 3. W pamięci zbiorowej postacie i wydarzenia z czasów minionych zostają przekształcone w symbole nie tylko postaw i wartości. Pamięć zbiorowa jest zbiorem symboli” ${ }^{64}$. Ważną rolę odgrywają tu - przywołajmy termin używany przez Pierre'a Norę - lieux de mémoire (miejsca pamięci): muzea, archiwa, cmentarze, festiwale, rocznice, traktaty, depozyty, pomniki, sanktuaria, bractwa, które na płaszczyźnie instytucjonalnej wspierają pamięć zbiorową ${ }^{65}$. Historia wskazuje preferowane wzorce zachowań na arenie międzynarodowej, tradycyjne zagrożenia i najlepiej rokujące sojusze.

Koncepcja lieux de mémoire kieruje nas do trzeciej składowej tożsamości, którą jest kultura. Szeroko rozumiana kultura (łącznie z językiem, sztuką, religią i zbiorowymi przekonaniami) umożliwia wspólnocie porozumiewanie się za sprawą jednego języka i kodu kulturowego. Jest nośnikiem łączących ją tradycji, w tym wiedzy o wspólnej historii. Stanowi repozytorium typowych dla jej członków symboli i wzorców zachowań. W tym sensie kultura stanowi być może najważniejszy czynnik jednoczący daną grupę społeczną ${ }^{66}$, a zarazem odróżniający ją od innych ${ }^{67}$. Pomniki kultury stają się symbolami danej wspólnoty, tak jak wieża Eiffla symbolizuje Paryż i całą Francję ${ }^{68}$.

Tożsamość jest konstrukcją społeczną. W jej analizie należy więc brać pod uwagę nie tylko elementy składowe, ale również tego, kto ją definiuje. $\mathrm{Na}$ gruncie nauki o stosunkach międzynarodowych pierwszoplanową rolę przypisuje się tu podmiotom reprezentującym dane państwo lub aktora pozapaństwowego. Wziąwszy jednak pod uwagę społeczno-kulturowy charakter tożsamości, należy uznać takie podejście za zbyt wąskie. Wskazane jest zatem badanie konstrukcji tożsamości na trzech płaszczyznach: elit politycznych (rządzących), elit kulturalnych i społeczeństwa.

63 M. Halbwachs, Społeczne ramy pamięci, Warszawa 2008, s. 4.

64 B. Szacka, Czas..., s. 48-50.

65 P. Nora, Między pamięcia a historia: Les lieux de Mémoire, „Tytuł Roboczy: Archiwum” 2009, nr 2, s. 4-12.

66 Por. P. Sztompka, Socjologia. Analiza spoleczeństwa, Kraków 2005, s. 124.

67 Por.: M. Golka, Socjologia kultury, Warszawa 2007; M. Bogucka, Kategorie i funkcje spoleczne kultury w perspektywie historycznej, Warszawa 2013.

68 A. Wallis, Socjologia wielkiego miasta, Warszawa 1967, s. 59. 
Według Michela Foucaulta elity to główni twórcy dominującego dyskur$\mathrm{su}^{69}$; dotyczy to w szczególności elit politycznych. Poprzez politykę oświatową, kulturalną ${ }^{70}$, medialną, a także zagraniczną rządzący wywierają zasadniczy wpływ na kształtowanie tożsamości danego podmiotu ${ }^{71}$. Realizują w ten sposób kilka celów polityki wewnętrznej i zagranicznej, takich jak wzmocnienie swojej legitymizacji, osłabienie wewnętrznych czy zewnętrznych oponentów, zjednoczenie wokół siebie danej społeczności i przekazanie jej wzorców zachowań zgodnych z własnymi wartościami. Tożsamość jest tu więc dogodnym instrumentem pozwalającym podnieść prestiż danego podmiotu zarówno na arenie wewnętrznej, jak i międzynarodowej ${ }^{72}$. W dużej mierze to na rządzących (czy szerzej: elitach politycznych) leży odpowiedzialność za kształtowanie tożsamości i jej ochronę w okresach przemian lub zewnętrznych zagrożeń. Polityka tożsamości nie może mieć jednak charakteru woluntarystycznego, gdyż nie osiągnie wówczas zamierzonych efektów. Poza wytyczeniem jasnego celu wymaga ona dobrej znajomości realiów społecznych oraz bliskiej współpracy ze społeczeństwem ${ }^{73}$. W warunkach globalizacji ochrona tożsamości jawi się jako jedno z ważnych zadań rządzących w sferach wewnętrznej i zewnętrznej. Jednocześnie tożsamość rozumiana jako marka czy wizerunek może być wykorzystana na arenie międzynarodowej jako instrument promocji.

Elity kulturalne (w tym przedstawiciele świata nauki i mediów) poprzez swoją działalność bezpośrednio kształtują tożsamość określonych podmiotów - przede wszystkim państw, narodów, regionów, miast, ale także związków wyznaniowych. Są nie tylko biernym nośnikiem danej kultury, ale także jej aktywnym wspóltwórcą. Pisarze i ludzie mediów odegrali ważną rolę w powstaniu czy odrodzeniu się narodowej tożsamości wielu europejskich etnosów, np. czeskiego ${ }^{74}$ czy walijskiego ${ }^{75}$. Istotną kwestią są w tym kontekście relacje między elitami kulturalnymi a politycznymi (rządzącymi), które zasadniczo

69 M. Foucault, Porządek dyskursu, Stowo/Obraz Terytoria, Gdańsk 2002, s. 32.

70 P. Majewski, Nacjonalistyczne kreowanie przestrzeni - projekt „Skopje 2014”, [w:] Konstrukcje i dekonstrukcje tożsamości, t. 3: Narracja i pamięć, red. E. Golachowska, A. Zielińska, Warszawa 2012, s. 197-210.

71 Por. A. Grosser, Les identités difficiles, Paris 1996, s. 70-87.

72 Por. J. Le Goff, Historia i pamięć, Warszawa 2007, s. 213.

73 D. Niedźwiedzki, Władza - tożsamość - zmiana społeczna, Kraków 2003, s. 205.

74 R. Szul, „Wskrzeszanie” języków jako symboli tożsamości, pamięci i przestrzeni narodów, [w:] Pamięć, przestrzeń..., s. 72-99.

75 B.H. Toszek, Wplyw regionalnej telewizji publicznej na ksztaltowanie tożsamości narodowej Walijczyków, [w:] Pejzaże tożsamości. Teoria i empiria w perspektywie interdyscyplinarnej, red. E. Litak, R. Furman, H. Bożek, Kraków 2011, s. 161-172. 
można sprowadzić do dwóch przypadków. W pierwszym, charakterystycznym zwłaszcza dla narodów mających własne państwo, elity kulturalne współdziałają z politycznymi, zazwyczaj odgrywając wobec nich rolę podrzędną. W drugim działają niezależnie od elit politycznych, a niekiedy wbrew nim, tak jak to ma zwykle miejsce w przypadku narodów pozbawionych własnego państwa.

Głównym adresatem polityki tożsamości realizowanej przez wspomniane wcześniej podmioty jest społeczeństwo (obywatele danego państwa, członkowie narodu, wyznawcy określonej religii); jest ono także jej wyrazicielem. Pojęcie pamięci historycznej bliskie jest do pamięci społecznej, a wzorce kulturowe to innymi słowy wzorce społeczne. Relacje pomiędzy społeczeństwem a elitami politycznymi i kulturalnymi są pochodną istniejącego systemu politycznego i kulturalnego. W demokracji społeczeństwo ma prawo wyboru swoich przedstawicieli, którzy będą kształtowali tożsamość ich wspólnoty zgodnie z jego preferencjami. Wolność słowa i gospodarka wolnorynkowa pozwalają społeczeństwu na analogicznych zasadach wpływać na elity kulturalne. W tych okolicznościach elity stają się instytucjonalnym rzecznikiem tożsamości danej grupy. W skonsolidowanym systemie autorytarnym elity polityczne mogą natomiast narzucić większości elit kulturalnych (a za ich pośrednictwem społeczeństwu) własny model tożsamości. Dotyczy to również polityki zagranicznej - społeczeństwo uważa za interes narodowy to, co zdefiniują pod tym pojęciem elity polityczne. $Z$ najmniej stabilną sytuacją mamy do czynienia $\mathrm{w}$ systemach politycznych o charakterze przejściowym, gdzie elity polityczne ani nie reprezentują społeczeństwa, ani nie są w stanie narzucić mu swojego dyskursu tożsamościowego. W takich okolicznościach społeczeństwo podejmuje próbę zdefiniowania swojej tożsamości na nowo, przy pomocy nowych elit politycznych czy kulturalnych. Często jest to wówczas - mówiąc językiem Castellsa - tożsamość oporu lub tożsamość projektu.

Otoczenie kształtuje tożsamość danego podmiotu zasadniczo na cztery sposoby: poprzez samą percepcję tego podmiotu, procesy internacjonalizacji określonych wzorców i zachowań, świadome i celowe działania na rzecz zmiany tożsamości danego podmiotu oraz analogiczne zabiegi podejmowane w celu jej ochrony.

Tożsamość zwykło się postrzegać przez pryzmat dwu relacji: „Kim jestem?" i „Za kogo mnie uważają?"76. Teza ta in extenso odnosi się również do tożsamości zbiorowych. Inny, nawet jeśli postrzega się go jako zagrożenie,

76 K. Strzyczkowski, Tożsamość w kontekście tendencji rozwojowych społeczeństwa ponowoczesnego, Warszawa 2012, s. 8. 
potrzebny jest do samookreślenia się ${ }^{77}$. Nieodłącznie wiążą się z tym zjawiska stereotypów i ról społecznych. Autostereotypy są pochodną tożsamości danej grupy, a stereotypy wykształcone przez innych wpływają na jej definiowanie $^{78}$. Rola społeczna jest natomiast systemem normatywnych wzorów zachowań lub oczekiwanych zachowań w danym otoczeniu. W stosunkach międzynarodowych mówimy o roli międzynarodowej danego podmiotu (przede wszystkim państwa), która określa wzorce postępowania pożądane przez jego środowisko międzynarodowe ${ }^{79}$.

Istotny wpływ na tożsamości międzynarodowe mają procesy internacjonalizacji. Poszczególne zbiorowości nie żyją w izolacji, a przepływ idei i ludzi sprawia, że do dyfuzji dochodzi także na gruncie tożsamości ${ }^{80}$. Tezę tę potwierdzają takie wydarzenia jak arabska wiosna w 2011 r., dlatego ważnym celem reżimów autorytarnych, czerpiących legitymizację z narzuconej społeczeństwu tożsamości, jest ograniczenie mu kontaktów ze światem zewnętrznym.

Tożsamość danego podmiotu może być świadomie i celowo kształtowana z zewnątrz. Charakterystyczne jest to dla relacji dominacji, np. pomiędzy metropolią i koloniami. Francja i Wielka Brytania za pośrednictwem systemu edukacji pozbawiły ludność tubylczą rdzennej tożsamości, zastępując ją anglo- i francuskojęzyczną, opartą o lojalność wobec mocarstwa kolonialnego ${ }^{81}$. Efektywność takiej polityki bywa różna, ale trzeba zauważyć, że nie musi być ona oparta na sile i nie zawsze zasługuje na ocenę krytyczną. Przykładem niech będzie działalność filantropijna amerykańskiego finansisty George'a Sorosa w krajach Europy Środkowej i Wschodniej, której celem jest zmiana samoidentyfikacji państw regionu - odrzucenie zamkniętej tożsamości narodowej na rzecz budowy tzw. społeczeństwa otwartego ${ }^{82}$.

Współcześnie ważnym celem jest ochrona tożsamości ludzkich zbiorowości zarówno na płaszczyźnie wewnętrznej (przynajmniej w wysokorozwiniętych państwach Zachodu), jak i międzynarodowej. W Europie najdalej idące działania w tym zakresie podjęła Rada Europy, czego rezultatem są

77 O. Wæver, Insecurity and identity unlimited, „Working Paper” (Kopenhaga) 1994, No. 14, s. 19.

78 Por. A.L. Strauss, Mirrors and masks. The search for identity, New York 1997.

79 M. Bielecka, Role międzynarodowe państw, [w:] Wstęp do teorii polityki zagranicznej państwa, red. R. Zięba, Toruń 2004, s. 177-192.

80 R.L. Jepperson, A. Wendt, P.J. Katzenstein, Norms..., s. 58.

81 M.F. Gawrycki, A. Szeptycki, Podporzadkowanie - niedorozwój-wyobcowanie. Postkolonializm a stosunki międzynarodowe, Warszawa 2011, s. 147.

82 Por. A. Porter, Buying a better world. George Soros and billionaire philanthropy, New York 2015. 
Europejska karta języków regionalnych lub mniejszościowych z $1992 \mathrm{r}{ }^{83}$ czy Konwencja ramowa o ochronie mniejszości narodowych z $1995 \mathrm{r}{ }^{84}$ Znaczenie tożsamości państw członkowskich uznaje również Unia Europejska ${ }^{85}$. Należy zarazem odnotować, że działania na rzecz ochrony tożsamości określonych grup nie spotykają się z jednoznaczną oceną. Ochrona taka może być bowiem dla wielkich mocarstw pretekstem do ingerencji w wewnętrzne sprawy mniejszych państw w celu realizacji własnych interesów. Dobrym przykładem są w tym kontekście działania Moskwy na rzecz wsparcia Rosjan żyjących w sąsiednich państwach poradzieckich ${ }^{86}$.

\section{Tożsamość międzynarodowa - przypadek Polski}

Rodzima tożsamość była przedmiotem zainteresowania i troski już w czasach przedrozbiorowych. Należy w tym miejscu przywołać przede wszystkim Mikołaja Reja, który w połowie XVI w. pisał w wierszu Do tego, co czytat: „A niechaj narodowie wżdy postronni znają, iż Polacy nie gęsi, iż swój język mają" ${ }^{87}$. Istotnymi cechami sarmackiej kultury szlacheckiej były przekonanie o wyższości własnych obyczajów i tradycji nad innymi oraz niechęć do napływu obcych wzorców ${ }^{88}$. W okresie rozbiorów sprawą o zasadniczym znaczeniu stało się przetrwanie polskiej tożsamości. Nie przypadkiem Jean-Jacques Rousseau pisał w Uwagach nad rzadem Polski: „W obecnym stanie rzeczy jeden tylko widzę sposób [...] ugruntować republikę w sercach Polaków tak, by się w nich utrzymała pomimo wszelkich wysiłków jej gnębicieli. [...] Jeżeli potraficie dokazać tego, by Polak nigdy nie mógł zostać Rosjaninem, ręczę wam, że Rosja nigdy nie ujarzmi Polski" ${ }^{99}$. Walka o kształt polskiej tożsamości była istotnym aspektem relacji między aparatem państwowo-partyjnym a społeczeństwem w okresie PRL. Również obecnie polska tożsamość jest przedmiotem badań i dyskusji na płaszczyźnie naukowej i politycznej, do czego w istotnym stopniu przyczyniło się członkostwo Polski w Unii Europejskiej i jego konsekwencje ${ }^{90}$. Brakuje co prawda kompleksowych badań

83 Dz.U., 2009, nr 137, poz. 1121.

84 Dz.U., 2002, nr 22, poz. 209.

85 Karta Praw Podstawowych: Dz.U. UE, C/83 z 30.03.2010 r., s. 391.

86 The "humanitarian dimension" of Russian foreign policy toward Georgia, Moldova, Ukraine and the Baltic States, ed. G. Pelnēns, Riga 2010.

87 Cyt. za: J. Bralczyk, Leksykon zdań polskich, Warszawa 2004, s. 14.

88 Por. J. Tazbir, Kultura szlachecka w Polsce. Rozkwit - upadek - relikty, Poznań 1998.

89 J.J. Rousseau, Uwagi nad rządem Polski, Kraków 1924, s. 10.

90 K. Strzyczkowski, Tożsamość..., s. 8. 
socjologicznych dotyczących współczesnego rozumienia pojęcia tożsamości narodowej w Polsce i jej składowych, ale istnieją dane cząstkowe. Zgodnie z badaniami CBOS z 2015 r. za najważniejsze cechy stanowiące o polskiej tożsamości ankietowani uznali uważanie się za Polaka, obywatelstwo polskie, polskość przynajmniej jednego z rodziców, zamieszkiwanie na stałe w Polsce, mówienie po polsku oraz przynależność do Kościoła katolickiego ${ }^{91}$.

W oparciu o wcześniejsze rozważania należy stwierdzić, że w pierwszej kolejności polską tożsamość określa geografia. Nie chodzi tu jednak o przekleństwo geopolityki, czyli rzekomo niekorzystne położenie pomiędzy Rosją a Niemcami ${ }^{92}$. Polska leży w Europie, a jej tożsamość opiera się na dziedzictwie grecko-rzymskim, dorobku chrześcijaństwa, tradycji państw narodowych oraz przywiązaniu do demokracji i społeczeństwa obywatelskiego. Ważną rolę odgrywa w tym kontekście pytanie, czy Polska jest częścią Wschodu, czy Zachodu: „Geograficznie - stwierdza Bohdan Cywiński - chodzi o wschód lub zachód Europy, psychologicznie - o świat wartości, z jakimi chcemy się utożsamiać i być utożsamiani" ${ }^{93}$. W dyskusjach o polskiej tożsamości, podobnie jak w większości państw europejskich, zwykło się uwypuklać elementy uważane za zachodnie, przeciwstawiając je stygmatyzującym cechom postrzeganym jako wschodnie ${ }^{94}$. Geografia to jednak nie tylko położenie Polski na mapie Europy i świata, ale także określone miejsca, które składają się na polską tożsamość, takie jak Bałtyk czy Tatry. To swoiste symbole Polski, a w opinii jej mieszkańców - zgodnie z badaniami prowadzonymi wśród uczniów polskich szkół - miejsca, bez których Polska nie byłaby Polską ${ }^{95}$. Analizując tożsamość Polaków przez pryzmat geografii warto wreszcie zwrócić uwagę na jej wymiar terytorialny. Społeczeństwo polskie jest relatywnie jednorodne, a tożsamość państwowo-narodowa zdecydowanie przeważa nad regionalną i lokalną ${ }^{96}$. Polskie regiony to w większości wyłącznie pojęcia statystyczno-geograficzne lub tzw. regiony reliktowe, które kiedyś cechowała odrębność, ale obecnie nie kształtują już tożsamości swoich

91 Tożsamość narodowa $i$ postrzeganie praw mniejszości narodowych $i$ etnicznych, oprac. M. Omyła-Rudzka, „Komunikat z Badań” (CBOS) 2015, nr 106, s. 6, dostępny także w internecie [dostęp: 26.11.2018]: <https://cbos.pl/SPISKOM.POL/2015/K_106_15.PDF> .

92 Przeklęte miejsce Europy? Dylematy polskiej geopolityki, red. J. Kloczkowski, Kraków 2009, s. 24.

93 B. Cywiński, Posłowie, [w:] K. Wóycicki, Nostalgia i polityka, Warszawa 2015, s. 103.

94 Z. Rykiel, Tożsamość terytorialna jako uczestnictwo $w$ kulturze, [w:] Tożsamość terytorialna w różnych skalach przestrzennych, red. Z. Rykiel, Rzeszów 2010, s. 26.

95 B. Szacka, Czas..., s. 120.

96 E. Kulczycka, Tożsamości regionalne w Polsce i Hiszpanii, [w:] Tożsamość terytorialna..., s. 137-138. 
mieszkańców. Obecnie najwyraźniejszy związek tożsamości z regionem widoczny jest na Kaszubach ${ }^{97}$. Poszczególne regiony nie aspirują do szerszego artykułowania swoich interesów na poziomie ogólnokrajowym, a spory polityczne nie przekładają się na antagonizmy międzyregionalne. Polsce nie grożą więc tendencje odśrodkowe ani ruchy separatystyczne.

Do historycznych składowych polskiej tożsamości zaliczają się takie elementy jak dziedzictwo kultury szlacheckiej, długotrwała obecność Rzeczypospolitej w Europie Wschodniej i tradycje przedmurza chrześcijaństwa, pozostałości etosu romantycznego, tradycje tolerancji religijnej i narodowej oraz dążenia wolnościowe w okresie zaborów, drugiej wojny światowej i PRL ${ }^{98}$. Jej nośnikiem jest pamięć historyczna - wspomnienia o ważnych dla państwa i narodu wydarzeniach i ludziach z przeszłości. Według współczesnych badań za najważniejsze wydarzenia z historii Polski do 1918 r. ankietowani uznają chrzest (966 r.), przyjęcie Konstytucji 3 maja (1791 r.) i bitwę pod Grunwaldem (1410 r.). Z ostatniego stulecia badani najczęściej wskazywali odzyskanie niepodległości w 1918 r., wybór Karola Wojtyły na papieża, przystą̧ienie Polski do Unii Europejskiej, upadek komunizmu w Polsce i najazd Niemiec z 1 września 1939 r. ${ }^{99}$ Największą sympatią ankietowanych cieszą się takie postacie historyczne jak: Jan Paweł II, Mikołaj Kopernik, Maria Skłodowska-Curie i Adam Mickiewicz. Należy zauważyć, że żadna z tych osób nie piastowała w Polsce stanowisk politycznych i dopiero na kolejnych miejscach znajdują się Józef Piłsudski, Mieszko I czy Lech Wałęsa. Negatywnymi bohaterami polskiej historii jawią się w opinii badanych przywódcy PRL: Wojciech Jaruzelski, Bolesław Bierut i Władysław Gomułka ${ }^{100}$. Ważną rolę odgrywają też dla Polaków miejsca pamięci, szczególnie te najbardziej znane: Wawel, Zamek Królewski w Warszawie, Pałac w Wilanowie, Łazienki Królewskie, Muzeum Pamięci Auschwitz-Birkenau i in. Według danych z 2013 r. każdy z tych obiektów odwiedziło ponad milion turystów z Polski i zagranicy ${ }^{101}$.

97 Z. Bokszański, Tożsamości..., s. 70-71.

98 Por. K. Łastawski, Polskość...

99 Świadomość historyczna Polaków, oprac. M. Bożewicz, „Komunikat z Badań” (CBOS) 2016, nr 68, s. 12, dostępny także w internecie [dostęp: 26.11.2018]: <https://www.cbos. pl/SPISKOM.POL/2016/K_068_16.PDF>.

100 J. Konieczna-Sałamatin, T. Stryjek, N. Otrishchenko, Wydarzenia, ludzie, historia. Raport z badań sondażowych o pamięci wspótczesnych Polaków $i$ Ukraińców, Warszawa 2018, dostępny w internecie [dostęp: 26.11.2018]: <https://depot.ceon.pl/bitstream/handle/123456789/15648/Wydarzenia_Ludzie_Historia_2018.pdf?sequence=1\&isAllowed=y >.

101 Por. Frekwencja $w$ atrakcjach turystycznych, oprac. Z. Kruczek, Kraków-Warszawa 2014, s. 30-34, dostępny w internecie [dostęp: 26.11.2018]: <https://www.pot.gov.pl/ component/rubberdoc/doc/4905/raw>. 
Kolejną składową tożsamości Polaków jest kultura. Ze względu na ponad stuletni okres zaborów, a następnie podporządkowanie ZSRR polska tożsamość rozwijała się w przeszłości w oparciu o model kulturowy właściwy narodom pozbawionym własnego państwa. Kształtowana była przez dzieła literackie pisarzy epoki romantyzmu (Adama Mickiewicza, Juliusza Słowackiego), pozytywizmu (Henryka Sienkiewicza, Bolesława Prusa) czy Młodej Polski (Stanisława Wyspiańskiego), które formowały powszechne wyobrażenie o państwie i narodzie: jego wyidealizowanej przeszłości (Trylogia, Pan Tadeusz) i współczesnych słabościach (Lalka, Wesele). Ich znajomość była niezbędnym atrybutem wykształconego człowieka. Literatura kształtowała również język polski, a niektóre cytaty przechodziły na stałe do mowy potocznej ${ }^{102}$. Istotne znaczenie miały również inne gałęzie sztuki: muzyka (Fryderyk Chopin), malarstwo (Jan Matejko), a od połowy XX w. kino (Andrzej Wajda). Rodzimi artyści stawali się rzecznikami sprawy polskiej i jej symbolami na arenie międzynarodowej zarówno ze względu na osiągnięcia artystyczne (szczególną rolę odgrywali w tym kontekście nobliści: Henryk Sienkiewicz, Władysław Reymont, Czesław Miłosz i w mniejszym stopniu Wisława Szymborska), jak i działalność polityczną (Ignacy Paderewski). Po odzyskaniu niepodległości w 1918, a następnie 1989 r. kultura narodowa zyskała wsparcie ze strony państwa. Kluczową rolę odgrywa tu system oświaty, którego zadanie polega na upowszechnianiu wśród dzieci i młodzieży jej dorobku. W praktyce można jednak postawić hipotezę, że współcześnie rola kultury jako składnika tożsamości narodowej spada ${ }^{103}$. Wiąże się to zarówno z faktem, że wobec odzyskania przez kraj niezależności artyści przestali pełnić rolę rzeczników sprawy polskiej („Ojczyzna moja wolna, wolna... / Więc zrzucam z ramion płaszcz Konrada" ${ }^{104}$ ), jak i z upowszechnieniem się kultury masowej, w zdecydowanej większości anglosaskiej ${ }^{105}$.

Istotnym elementem polskiej kultury i tożsamości jest religia katolicka obrządku łacińskiego. W Polsce żyje ok. 33 mln osób ochrzczonych w Kościele

102 J. Kołodziejska, Kanon literacki we współczesnym obiegu czytelniczym, [w:] Społeczeństwo informacyjne i jego technologie, red. B. Sosińska-Kalata, K. Materska, W. Gliński, Warszawa 2004, s. 27-38.

103 Według badań z 2007 r. jako lekturę dla dzieci Trylogie, W pustyni $i$ w puszczy czy Krzyżaków Henryka Sienkiewicza poleciłoby 4,7\% ankietowanych, a Pana Tadeusza - 1,5\%. Czytamy dzieciom, oprac. J. Szczepańska, „Komunikat z Badań” (CBOS) 2007, nr 132, s. 7, dostępny w internecie [dostęp: 26.11.2018]: <https://www.cbos.pl/SPISKOM.POL/ 2007/K_132_07.PDF>.

104 A. Słonimski, Czarna wiosna, [w:] tegoż, Wiersze zebrane, Warszawa 1929, s. 143.

105 Por. A. Dudziak, Kultura narodowa w dobie globalizacji, „Przegląd Politologiczny” 2010, nr 1, s. 125-139. 
katolickim (blisko $85 \%$ społeczeństwa) ${ }^{106}$, ale na niedzielną mszę uczęszcza już mniej niż $40 \%$ zobowiązanych do tego wiernych ${ }^{107}$. Według badań Pew Research Center 64\% ankietowanych uważa religię katolicką za ważną składową polskiej tożsamości ${ }^{108}$. Wybrane miejsca kultu, jak częstochowska Jasna Góra i krakowskie Łagiewniki, przyciągają rokrocznie więcej pielgrzymów niż najpopularniejsze w Polsce atrakcje turystyczne ${ }^{109}$, stając się w ten sposób swoistymi lieux de mémoire.

W praktyce należy sądzić, że spośród wymienionych wyżej składowych polską tożsamość kształtują obecnie przede wszystkim historia i religia. Geografia z powodu względnej jednorodności geograficznej społeczeństwa polskiego, a także stałości polskich granic po 1945 r. nie jest przedmiotem debaty publicznej (Bałtyk i Tatry jawiły się zapewne Polakom jako swoiste symbole ojczyzny zarówno w okresie PRL, jak i po 1989 r.). Kultura, w jej wymiarze tożsamościowym, jest w Polsce przede wszystkim nośnikiem historii, a nie jak w przypadku niektórych innych państw - narodowego folkloru.

W ciągu ostatnich dwustu lat kolejni suwereni podejmowali szeroko zakrojone działania mające na celu osłabienie i zmianę tożsamości Polaków. W czasie zaborów wysiłki na rzecz wyniszczenia polskich elit, zwłaszcza po powstaniach listopadowym (1831 r.) i styczniowym (1863 r.), łączyły się z polityką rusyfikacji i germanizacji. Wyjątkiem był zabór austriacki, gdzie Polacy zyskali w drugiej połowie XIX w. większą swobodę działania, i to zarówno na płaszczyźnie kulturalnej, jak i politycznej ${ }^{110}$. Po 1945 r. komuniści podjęli próbę ukształtowania nowej polskiej tożsamości, zgodnej z ideologią marksistowsko-leninowską oraz interesami własnymi i Związku Radzieckiego. Poza narracją historyczną, ukazującą przeszłość w kategoriach walki klasowej, składały się na nią: nieufność wobec Zachodu, w szczególności Niemiec (RFN), przyjaźń z ZSRR, mit o powrocie do piastowskich granic i dawnej przynależności Ziem Zachodnich do Polski ${ }^{111}$, walka z religią katolicką, którą postrzegano jako

106 Maty rocznik statystyczny Polski, Warszawa 2018, s. 114, dostępny także w internecie [dostęp: 26.11.2018]: <https://stat.gov.pl/download/gfx/portalinformacyjny/pl/defaultaktualnosci/5515/1/19/1/maly_rocznik_statystyczny_polski_2018.pdf > .

107 Praktyki niedzielne Polaków (dominicantes), „Instytut Statystyki Kościoła Katolickiego SAC” [online, dostęp: 26.11.2018], dostępny w internecie: <http://www.iskk.pl/badania/ religijnosc/211-praktyki-niedzielne-polakow-dominicantes $>$.

108 A. Cooperman, S. Gardner, N. Sahgal i in., Eastern and western Europeans differ...

109 Frekwencja w atrakcjach..., s. 31.

110 Por. M. Bogucka, Dzieje kultury polskiej do 1918 roku, Wrocław 1991, s. 258-402.

$111 \mathrm{~K}$. Taborska, Kreowanie pamięci nowego niemiecko-polskiego pograniczna w wybranych tekstach, [w:] Konstrukcje i dekonstrukcje..., s. 64. 
ważny element tożsamości narodowej ${ }^{112}$, czy wreszcie upowszechnienie w języku polskim rusycyzmów ${ }^{113}$. Polska kultura miała być, przynajmniej początkowo, taka jak w ZSRR - „,narodowa w formie, ale socjalistyczna w treści”114. Działania te okazały się jednak w dużej mierze bezowocne, co wynikało z siły istniejącej tożsamości narodowej, przywiązania do niej społeczeństwa, a także postawy elit kulturalnych, które nawet jeśli działały w ramach oficjalnych instytucji, w większości nie zrezygnowały ze swojej tożsamościowotwórczej roli.

Jesień Ludów świadczyła o fiasku polityki ZSRR mającej na celu wykształcenie wspólnej blokowej tożsamości. Odrzucenie radzieckiej dominacji przez Polskę i inne państwa satelickie warunkowane było $\mathrm{w}$ istotnym stopniu odrodzeniem w nich tożsamości środkowo-, a nie wschodnioeuropejskiej oraz poczuciem odrębności od ZSRR ${ }^{115}$. Dążenie władz Polski do członkostwa w instytucjach zachodnich, przede wszystkim w Unii Europejskiej, miało wymiar nie tylko gospodarczy i strategiczny, ale również tożsamościowy. Powrót do Europy rozumiano jako demokratyczną i cywilizacyjną przebudowę, odzyskanie europejskiej tożsamości poprzez odrzucenie dziedzictwa okresu komunizmu ${ }^{116}$.

Wydawało się, że w zasadniczym stopniu cel ten zrealizowany został wraz z przystąpieniem Polski do UE. Transformacja tożsamościowa okazała się jednak nietrwała i odwracalna. Punktem zwrotnym dla tego procesu stało się zwycięstwo Prawa i Sprawiedliwości w wyborach prezydenckich i parlamentarnych w 2015 r. Partia rządząca podjęła aktywne działania na rzecz ukształtowania tożsamości polskiego społeczeństwa zgodnie z własnymi koncepcjami politycznymi i oczekiwaniami swego elektoratu. Wśród najważniejszych należy wymienić politykę kulturalną, która premiuje podmioty o orientacji konserwatywno-narodowej ${ }^{117}$, a także nową politykę historyczną, gdzie naród

112 D. Thiriet, Marks czy Maryja. Komuniści i Jasna Góra w apogeum stalinizmu (1950-1956), Warszawa 2002, s. 17.

113 A. Skrzypek, Polska w orbicie politycznej ZSRR, [w:] W objęciach Wielkiego Brata. Sowieci w Polsce 1944-1993, red. K. Rokicki, S. Stępień, Warszawa 2009, s. 38-43.

114 Por. R. Pipes, Rosja bolszewików, Warszawa 2005, s. 159-161.

115 Z. Brzeziński, Wielkie bankructwo. Narodziny i śmierć komunizmu w XX wieku, Paryż 1990, s. 149-150.

116 R. Kuźniar, Krzysztofa Skubiszewskiego powrót Polski do Europy, [w:] Krzysztof Skubiszewski. Minister Spraw Zagranicznych RP 1989-1993, red. P. Skubiszewski, J. Stańczak, Warszawa 2016, s. 81-82. Por. R. Bäcker, Mit PRL-u jako symboliczny znak antywartości lub syndrom zbiorowej tożsamości, [w:] Wartości a polityka, red. D. Walczak-Duraj, Łódź 1999, s. 11-24.

117 Por. np. wyniki pierwszego naboru wniosków o dofinansowanie czasopism wraz z odwołaniami: „Ministerstwo Kultury i Dziedzictwa Narodowego” [online], 4.06.2018 [dostęp: 26.11.2018], dostępny w internecie: $<$ http://www.mkidn.gov.pl/media/po2018/dokumenty/ 20180604_karta_publikacji_-_Czasopisma18_04_06_2018_odwolania.pdf $>$. 
i państwo polskie przedstawia się w roli bohaterów lub męczenników, ignorując jednocześnie mniej chwalebne epizody z najnowszych dziejów Polski, czego przykładem była kontrowersyjna zmiana ustawy o Instytucie Pamięci Narodowej z 2018 r., zakazująca obarczania Polski i Polaków współodpowiedzialnością za zbrodnie z okresu drugiej wojny światowej ${ }^{118}$. PiS kwestionuje nie tylko znaczenie przemian 1989 r., ale i przynależności do Unii Europejskiej, która w jego narracji jawi się nie jako wspólnota, której Polska jest częścią, ale instytucja zagrażająca suwerenności i tożsamości kraju. Odejściu od wartości demokratycznych i europejskich towarzyszy rosnąca akceptacja dla postaw autorytarnych i ksenofobicznych, co jest przejawem kryzysu tożsamości europejskiej ${ }^{119}$. Prowadzenie takiej polityki wpływa na społeczeństwo. Co prawda deklaratywnie Polacy popierają członkostwo w Unii Europejskiej, ale w praktyce ich stosunek do wspólnoty i jej działań jest krytyczny: sprzeciwiają się pogłębieniu integracji europejskiej, przystąpieniu Polski do strefy euro, przyjmowaniu do kraju uchodźców z Afryki i Bliskiego Wschodu. Ta zamknięta postawa koreluje z polityką PiS i w dużej mierze tłumaczy wciąż wysoką popularność tej formacji ${ }^{120}$.

O ile na arenie wewnętrznej polityka tożsamościowa PiS przynosi wymierne korzyści polityczne, o tyle w sferze międzynarodowej rodzi negatywne następstwa. Od 2015 r. wizerunek Polski uległ istotnemu pogorszeniu, co potwierdzają zarówno oficjalne dokumenty MSZ, jak i badania opinii publicznej w wybranych krajach. „Ogólny obraz Polski w mediach światowych - stwierdza raport z początku 2018 r. - nie może być uznany za pozytywny. Polska polityka zagraniczna była niezrozumiana i krytykowana, negatywnie oceniane były również przeprowadzane aktualnie w naszym kraju reformy wewnętrzne. [...] Najwięcej niechętnych, a nawet otwarcie negatywnych ocen polskiej polityki zagranicznej pojawiało się w prasie zachodnioeuropejskiej (Niemcy, Wielka Brytania, Włochy). [...] Zwraca uwagę coraz wyraźniejsze oddzielanie ocen działań polityków i zmian politycznych w Polsce (oceny negatywne) od generalnie pozytywnego obrazu samych Polaków i naszych osiągnięć

118 Dz.U., 2018, poz. 369.

119 A.M. Ostrowska, Tożsamość europejska w kryzysie - stan badań i perspektywy dalszego rozwoju, „Studia Europejskie” 2016, nr 4, s. 117.

120 Por. A. Balcer i in., Polacy wobec UE: koniec konsensusu, „Fundacja Batorego” [online], grudzień 2016 [dostęp: 26.11.2018], dostępny w internecie: <http:/www.batory. org.pl/upload/files/Programy\%20operacyjne/Otwarta\%20Europa/Polacy\%20wobec\%20 UE\%20-\%20 r.port\%20Fundacji\%20Batorego.pdf>. 
kulturalnych i naukowych"121. Dla przykładu Niemcy, choć pozytywnie odnoszą się do Polaków i Polski, częściej niż w ostatnich latach postrzegają ją obecnie przez pryzmat historii i polityki; w tej ostatniej kategorii dominują zaś skojarzenia negatywne: „niedobre dla Europy”, ,prawicowy rząd”, „dyktatura" ${ }^{122}$. Poziom sympatii do Polski spadł również na Ukrainie $-\mathrm{z}$ rekordowych 58\% we wrześniu 2015 r. do 48\% w marcu $2018^{123}$. Paradoksalnie wzrost niechęci wobec Polski (a właściwie jej władz) może sprzyjać polityce tożsamościowej PiS, służąc za dogodny argument na rzecz tezy o wrogości zewnętrznego otoczenia wobec naszego kraju.

$$
* * *
$$

Tożsamość to jedno z węzłowych pojęć we współczesnych stosunkach międzynarodowych. $Z$ jednej strony w obliczu postępującej globalizacji rosną obawy, czy zbiorowym tożsamościom uda się przetrwać, co zmusza też do refleksji na temat ich istoty. $Z$ drugiej natomiast nie sposób nie dostrzec, że konflikty międzynarodowe - zwłaszcza od zakończenia zimnej wojny - coraz częściej mają wymiar tożsamościowy. Zagadnienie tożsamości wciąż jest niedoceniane na gruncie nauki o stosunkach międzynarodowych, w szczególności nauki polskiej, w której dominuje podejście realistyczne i instytucjonalne. Nawet gdy bierze się ją pod uwagę, badacze marginalizują jej zmienność i kształtujące ją czynniki ${ }^{124}$. Refleksja na temat tożsamości podmiotów zbiorowych, jak państwa czy narody, podejmowana jest więc częściej na gruncie innych nauk społecznych, np. socjologii.

Dystans badaczy do pojęcia tożsamości wynika po części z problemów, jakie rodzi zastosowanie go na gruncie naukowym. Tożsamość to kategoria o charakterze badawczym, ale też potocznym i ideologicznym ${ }^{125}$.

121 M. Wierzejska, J. Dziedziczak, Obecność i postrzeganie Polski w mediach zagranicznych w roku 2017 (na podstawie doniesień z placówek), 2.09.2018 [dostęp: 26.11.2018], dostępny w internecie: <http://bi.gazeta.pl/im/2/23055/m23055222,MSZ.pdf>.

122 A. Łada, Trudne partnerstwo. Polacy i Niemcy o kraju sąsiada, wspólnej historii i Europie, Warszawa 2018, s. 15.

123 Public opinion survey of residents of Ukraine, March 15-31, 2018, „International Republican Institute" [online, dostęp: 26.11.2018], dostępny w internecie: $<$ http://www.iri. org/sites/default/files/2018-5-21_ukraine_poll_presentation_0.pdf >

124 Por. B. Bucher, U. Jasper, Revisiting 'identity' in international relations. From identity as substance to identifications in action, „European Journal of International Relations” 2017, vol. 23, issue 2, s. 391-415.

125 Por. R. Brubaker, F. Cooper, Beyond “identity”, „Theory and Society” 2000, vol. 29, No. 1 , s. 4-5. 
Ponadto jej definicje są w większości nieprecyzyjne, a zakres podmiotowy i przedmiotowy - nadmiernie szeroki. Trzeba jednak mieć na uwadze fakt, że tożsamość jest konstrukcją społeczną - definiowaną przez grupy, które same i zgodnie z własnymi odczuciami decydują, co stanowi o ich istocie.

\section{Bibliografia}

Bäcker R., Mit PRL-u jako symboliczny znak antywartości lub syndrom zbiorowej tożsamości, [w:] Wartości a polityka, red. D. Walczak-Duraj, Łódź 1999.

Balcer A. i in., Polacy wobec UE: koniec konsensusu, „Fundacja Batorego” [online], grudzień 2016 [dostęp: 26.11.2018], dostępny w internecie: <http://www.batory.org.pl/upload/files/Programy\%20operacyjne/Otwarta\%20Europa/Polacy\%20wobec\%20UE\%20-\%20 r. port $\% 20$ Fundacji\%20Batorego.pdf $>$.

Barber B.R., Dżihad kontra McŚwiat, Warszawa 2007.

Bergbauer S., Explaining European identity formation. Citizens' attachment from Maastricht Treaty to crisis, Cham 2017.

Berger T.U., Norms, identity and national security in Germany and Japan, [w:] The culture of national security. Norms and identity in world politics, ed. P.J. Katzenstein, New York 1996.

Bielecka M., Role międzynarodowe państw, [w:] Wstęp do teorii polityki zagranicznej państwa, red. R. Zięba, Torun 2004.

Bieleń S., Tożsamość i interesy narodowe w procesach identyfikacji międzynarodowej państw, [w:] Porządek międzynarodowy u progu XXI wieku, red. R. Kuźniar, Warszawa 2005.

Bogucka M., Dzieje kultury polskiej do 1918 roku, Wrocław 1991.

Bogucka M., Kategorie i funkcje społeczne kultury w perspektywie historycznej, Warszawa 2013.

Bokszański Z., Tożsamości zbiorowe, Warszawa 2005.

Bralczyk J., Leksykon zdań polskich, Warszawa 2004.

Brzeziński Z., Wielkie bankructwo. Narodziny i śmierć komunizmu w XX wieku, Paryż 1990.

Bucher B., Jasper U., Revisiting 'identity' in international relations. From identity as substance to identifications in action, „European Journal of International Relations” 2017, vol. 23, issue 2 .

Buzan B., Wæver O., Wilde J. de, Security. A new framework for analysis, Boulder 1998.

Castells M., Wiek informacji: ekonomia, społeczeństwo i kultura, t. 2: Siła tożsamości, Warszawa 2008.

Cooperman A., Gardner S., Sahgal N. i in., Eastern and western Europeans differ on importance of religion, views of minorities, and key social issues, 29.10.2018 [dostęp: 26.11.2018], dostępny w internecie: <http://www.pewforum.org/wp-content/uploads/sites/7/2018/10/ Eastern-Western-Europe-FOR-WEB-1.pdf $>$.

The culture of national security. Norms and identity in world politics, ed. P.J. Katzenstein, New York 1996.

Cywiński B., Posłowie, [w:] K. Wóycicki, Nostalgia i polityka, Warszawa 2015.

Czaputowicz J., Teorie stosunków międzynarodowych. Krytyka i systematyzacja, Warszawa 2007.

Czytamy dzieciom, oprac. J. Szczepańska, „Komunikat z Badań” (CBOS) 2007, nr 132, dostępny w internecie [dostęp: 26.11.2018]: <https://www.cbos.pl/SPISKOM.POL/2007/K_132_07. PDF>. 
Deschamps J.-C., Devos T., Regarding the relationship between social identity and personal identity, [w:] Social identity. International perspectives, ed. S. Worchel i in., LondonThousand Oaks-New Delhi 1998.

Dudziak A., Kultura narodowa $w$ dobie globalizacji, „Przegląd Politologiczny” 2010, nr 1.

Dyczewski L., Kultura lokalna a tożsamość, [w:] Region, tożsamość, edukacja, red. J. Nikitorowicz, D. Misiejuk, M. Sobecki, Białystok 2005.

European citizenship. Report, „Standard Eurobarometer” 2016, vol. 85, dostępny w internecie [dostęp: 26.11.2018]: <https://ec.europa.eu/commfrontoffice/publicopinion/index.cfm/ ResultDoc/download/DocumentKy/75905>.

The European Union's emerging international identity. Views from the global arena, ed. H. de Waele, J.-J. Kuipe, Leiden-Boston 2013.

Foucault M., Porządek dyskursu, Gdańsk 2002.

Frekwencja $w$ atrakcjach turystycznych, oprac. Z. Kruczek, Kraków-Warszawa 2014, dostępny w internecie [dostęp: 26.11.2018]: <https://www.pot.gov.pl/component/rubberdoc/ doc/4905/raw $>$.

Fuchs D., Klingemann H.-D., Eastward enlargement of the European Union and the identity of Europe, „West European Politics” 2002, vol. 25, No. 2.

Gawrycki M.F., Szeptycki A., Podporządkowanie - niedorozwój - wyobcowanie. Postkolonializm a stosunki międzynarodowe, Warszawa 2011.

Globalizacja-naród - jednostka. Zagadnienia tożsamości kulturowej, red. T. Kuczur, A. Błachnio, Toruń 2009.

Golka M., Socjologia kultury, Warszawa 2007.

Grosser A., Les identités difficiles, Paris 1996.

Grzybowski J., Byt, Tożsamość, Naród. Próba wyjaśnienia formuły „tożsamość narodowa” w perspektywie metafizyki, Kęty 2012.

Habermas J., Obywatelstwo a tożsamość narodowa. Rozważania nad przyszłościa Europy, Warszawa 1993.

Hagstrom L., Identity change and foreign policy. Japan and its 'others', Abingdon-New York 2015.

Halbwachs M., Społeczne ramy pamięci, Warszawa 2008.

Haliżak E., Regionalizm w stosunkach międzynarodowych, [w:] Stosunki międzynarodowe. Geneza, struktura, dynamika, red. E. Haliżak, R. Kuźniar, Warszawa 2006.

Heidegger M., Identyczność i różnica, Warszawa 2010.

Hopf T., Allan B. B., Making identity count. Building a national identity database, Oxford 2016.

The "humanitarian dimension" of Russian foreign policy toward Georgia, Moldova, Ukraine and the Baltic States, ed. G. Pelnēns, Riga 2010.

Huntington S., Zderzenie cywilizacji i nowy ksztalt ładu światowego, Warszawa 1997.

Identity, migration and the new security agenda in Europe, ed. O. Wæver i in., BasingstokeNew York 1993.

Izenberg G., Identity. The necessity of a modern idea, Philadelphia 2016.

Jackson R., Sørensen G., Wprowadzenie do stosunków międzynarodowych. Teorie i kierunki badawcze, Kraków 2006.

Jepperson R.L., Wendt A., Katzenstein P.J., Norms, identity and culture in national security, [w:] The culture of national security. Norms and identity in world politics, ed. P.J. Katzenstein, New York 1996.

Kagan R., Potęga i Raj. Ameryka i Europa w nowym porządku świata, Warszawa 2003. 
Keting M., National and regional identities in Europe, „Contemporary European History” 2007, vol. 16, No. 3 .

Kłoskowska A., Kultury narodowe u korzeni, Warszawa 2005.

Kołakowski L., Moje stuszne poglądy na wszystko, Kraków 1999.

Kołakowski L., O tożsamości zbiorowej, [w:] L. Kołakowski, Moje stuszne poglądy na wszystko, Kraków 1999.

Kołodziejska J., Kanon literacki we współczesnym obiegu czytelniczym, [w:] Społeczeństwo informacyjne i jego technologie, red. B. Sosińska-Kalata, K. Materska, W. Gliński, Warszawa 2004.

Konieczna-Sałamatin J., Stryjek T., Otrishchenko N., Wydarzenia, ludzie, historia. Raport $z$ badań sondażowych o pamięci wspótczesnych Polaków i Ukraińców, Warszawa 2018, dostępny w internecie [dostęp: 26.11.2018]: <https:/depot.ceon.pl/bitstream/handle/123456789/15648/Wydarzenia_Ludzie_Historia_2018.pdf?sequence=1\&isAllowed=y $>$.

Konstrukcje i dekonstrukcje tożsamości, t. 3: Narracja i pamięć, red. E. Golachowska, A. Zielińska, Warszawa 2012.

Kręgi integracji i rodzaje tożsamości. Polska, Europa, świat, red. W. Wesołowski, J. Włodarek, Warszawa 2005.

Krzysztof Skubiszewski. Minister Spraw Zagranicznych RP 1989-1993, red. P. Skubiszewski, J. Stańczak, Warszawa 2016.

Kuczur T., Tożsamość kulturowa vs. tożsamość polityczna (przykład Niemiec i Francji) - europejskie koncepcje samookreślenia się jednostki, [w:] Globalizacja-naród-jednostka. Zagadnienia tożsamości kulturowej, red. T. Kuczur, A. Błachnio, Toruń 2009.

Kukułka J., Pojmowanie i istota tożsamości narodowej pod koniec XX wieku, [w:] Nowa tożsamość Niemiec i Rosji w stosunkach międzynarodowych, red. S. Bieleń, W. M. Góralski, Warszawa 1999.

Kukułka J., Zaspokajanie potrzeb i rozwiąywanie konfliktów w stosunkach międzynarodowych, [w:] Stosunki międzynarodowe. Geneza, struktura, dynamika, red. E. Haliżak, R. Kuźniar, Warszawa 2006.

Kulczycka E., Tożsamości regionalne w Polsce i Hiszpanii, [w:] Tożsamość terytorialna w różnych skalach przestrzennych, red. Z. Rykiel, Rzeszów 2010.

Kultura w stosunkach międzynarodowych, red. H. Schreiber, G. Michałowska, Warszawa 2013.

Kuźniar R., Krzysztofa Skubiszewskiego powrót Polski do Europy, [w:] Krzysztof Skubiszewski. Minister Spraw Zagranicznych RP 1989-1993, red. P. Skubiszewski, J. Stańczak, Warszawa 2016.

Labuda G., Kaszubi i ich dzieje, Gdańsk 1996.

Laitin D.D., Culture and national identity. "The East” and European integration, „West European Politics" 2002.

Le Goff J., Historia i pamięć, Warszawa 2007.

Lebow R.N., The politics and ethics of identity. In search of ourselves, Cambridge 2012.

Łada A., Trudne partnerstwo. Polacy i Niemcy o kraju sąsiada, wspólnej historii i Europie, Warszawa 2018.

Łastawski K., Polskość w Europie. Polska tożsamość narodowa w jednoczącej się Europie, Warszawa 2004.

Łoś-Nowak T., Państwowy poziom analizy w stosunkach międzynarodowych, [w:] Poziomy analizy stosunków międzynarodowych, t. 1, red. E. Haliżak, M. Pietraś, Warszawa 2013. 
Maffesoli M., Czas plemion. Schyłek indywidualizmu w społeczeństwach ponowoczesnych, Warszawa 2008.

Majewski P., Nacjonalistyczne kreowanie przestrzeni-projekt ,, Skopje 2014”, [w:] Konstrukcje i dekonstrukcje tożsamości, t. 3: Narracja i pamięć, red. E. Golachowska, A. Zielińska, Warszawa 2012.

Mały rocznik statystyczny Polski, Warszawa 2018, dostępny także w internecie [dostęp: 26.11.2018]: <https://stat.gov.pl/download/gfx/portalinformacyjny/pl/defaultaktualnosci/ 5515/1/19/1/maly_rocznik_statystyczny_polski_2018.pdf $>$.

Mamzer H., Tożsamość w podróży. Wielokulturowość a ksztaltowanie tożsamości jednostki, Poznań 2003.

McSweeney B., Security, identity and interests. A sociology of international relations, Cambridge 1999.

Measuring identity. A guide for social scientists, ed. R. Abdelal i in., Cambridge 2009.

Niedźwiedzki D., Władza - tożsamość - zmiana społeczna, Kraków 2003.

Nora P., Między pamięcia a historią: Les lieux de Mémoire, „Tytuł Roboczy: Archiwum” 2009, nr 2.

Nowa tożsamość Niemiec i Rosji w stosunkach międzynarodowych, red. S. Bieleń, W.M. Góralski, Warszawa 1999

Ossowski S., O ojczyźnie i narodzie, Warszawa 1984.

Ostrowska A.M., Tożsamość europejska w kryzysie - stan badań i perspektywy dalszego rozwoju, „Studia Europejskie” 2016, nr 4.

Pamięć, przestrzeń, tożsamość, red. S. Kapralski, Warszawa 2010.

Peabody D., National characteristics, Cambridge 1985.

Pejzaże tożsamości. Teoria i empiria w perspektywie interdyscyplinarnej, red. E. Litak, R. Furman, H. Bożek, Kraków 2011.

Pipes R., Rosja bolszewików, Warszawa 2005.

Pirveli M., Duch miejsca a topofilia, [w:] Pamięć, przestrzeń, tożsamość, red. S. Kapralski, Warszawa 2010.

Porter A., Buying a better world. George Soros and billionaire philanthropy, New York 2015.

Porządek międzynarodowy u progu XXI wieku, red. R. Kuźniar, Warszawa 2005.

Poziomy analizy stosunków międzynarodowych, t. 1, red. E. Haliżak, M. Pietraś, Warszawa 2013.

Praktyki niedzielne Polaków (dominicantes), „Instytut Statystyki Kościoła Katolickiego SAC” [online, dostęp: 26.11.2018], dostępny w internecie: <http://www.iskk.pl/badania/religijnosc/211-praktyki-niedzielne-polakow-dominicantes>.

Przeklęte miejsce Europy? Dylematy polskiej geopolityki, red. J. Kloczkowski, Kraków 2009.

Public opinion survey of residents of Ukraine, March 15-31, 2018, „International Republican Institute" [online, dostęp: 26.11.2018], dostępny w internecie: $<$ http://www.iri.org/sites/ default/files/2018-5-21_ukraine_poll_presentation_0.pdf $>$.

Region, tożsamość, edukacja, red. J. Nikitorowicz, D. Misiejuk, M. Sobecki, Białystok 2005.

The return of culture and identity in IR theory, ed. Y. Lapid, F. V. Kratochwil, Boulder 1996.

Rousseau J.J., Uwagi nad rzadem Polski, Kraków 1924.

Ruggie J.G., What makes the world hang together? Neo-utilitarianism and the social constructivist challenge, „International Organization” 1998, vol. 52, No. 4.

Rykiel Z., Tożsamość terytorialna jako uczestnictwo w kulturze, [w:] Tożsamość terytorialna w różnych skalach przestrzennych, red. Z. Rykiel, Rzeszów 2010. 
Schreiber H., Michałowska G., Wprowadzenie. Zwrot kulturowy w stosunkach międzynarodowych, [w:] Kultura w stosunkach międzynarodowych, red. H. Schreiber, G. Michałowska, Warszawa 2013.

Skarga B., Tożsamość i różnica. Eseje metafizyczne, Kraków 2009.

Skrzypek A., Polska w orbicie politycznej ZSRR, [w:] W objęciach Wielkiego Brata. Sowieci w Polsce 1944-1993, red. K. Rokicki, S. Stępień, Warszawa 2009.

Słonimski A., Czarna wiosna, [w:] A. Słonimski, Wiersze zebrane, Warszawa 1929.

Słonimski A., Wiersze zebrane, Warszawa 1929.

Smith A.D., National identity and the idea of European unity, „International Affairs” 1992, vol. 68 , No. 1.

Social identity. International perspectives, ed. S. Worchel i in., London-Thousand Oaks-New Delhi 1998.

Społeczeństwo informacyjne i jego technologie, red. B. Sosińska-Kalata, K. Materska, W. Gliński, Warszawa 2004.

Stokes B., Stewart R., What it takes to truly be 'one of us', 1.02.2017 [dostęp: 26.11.2018], dostępny w internecie: <https:/assets.pewresearch.org/wp-content/uploads/sites/2/2017/04/14094140/Pew-Research-Center-National-Identity-Report-FINAL-February-1-2017.pdf > .

Stosunki międzynarodowe. Geneza, struktura, dynamika, red. E. Haliżak, R. Kuźniar, Warszawa 2006.

Strauss A.L., Mirrors and masks. The search for identity, New York 1997.

Strzyczkowski K., Tożsamość w kontekście tendencji rozwojowych spoleczeństwa ponowoczesnego, Warszawa 2012.

Szacka B., Czas przeszły, pamięć, mit, Warszawa 2006.

Szczepański M.S., Społeczności lokalne i regionalne a ład kontynentalny, [w:] Kręgi integracji i rodzaje tożsamości. Polska, Europa, świat, red. W. Wesołowski, J. Włodarek, Warszawa 2005.

Sztompka P., Socjologia. Analiza społeczeństwa, Kraków 2005.

Szul R., ,, Wskrzeszanie” języków jako symboli tożsamości, pamięci i przestrzeni narodów, [w:] Pamięć, przestrzeń, tożsamośćc, red. S. Kapralski, Warszawa 2010.

Świadomość historyczna Polaków, oprac. M. Bożewicz, „Komunikat z Badań” (CBOS) 2016, nr 68, dostępny także w internecie [dostęp: 26.11.2018]: <https://www.cbos.pl/SPISKOM. POL/2016/K_068_16.PDF>.

Taborska K., Kreowanie pamięci nowego niemiecko-polskiego pograniczna w wybranych tekstach, [w:] Konstrukcje i dekonstrukcje tożsamości, t. 3: Narracja i pamięć, red. E. Golachowska, A. Zielińska, Warszawa 2012.

Tazbir J., Kultura szlachecka w Polsce. Rozkwit - upadek - relikty, Poznań 1998.

Thiriet D., Marks czy Maryja. Komuniści i Jasna Góra w apogeum stalinizmu (1950-1956), Warszawa 2002.

Toszek B.H., Wpływ regionalnej telewizji publicznej na ksztaltowanie tożsamości narodowej Walijczyków, [w:] Pejzaże tożsamości. Teoria i empiria w perspektywie interdyscyplinar$n e j$, red. E. Litak, R. Furman, H. Bożek, Kraków 2011.

Tożsamość narodowa $i$ postrzeganie praw mniejszości narodowych $i$ etnicznych, oprac. M. Omyła-Rudzka, „Komunikat z Badań” (CBOS) 2015, nr 106, dostępny także w internecie [dostęp: 26.11.2018]: <https://cbos.pl/SPISKOM.POL/2015/K_106_15.PDF>.

Tożsamość terytorialna w różnych skalach przestrzennych, red. Z. Rykiel, Rzeszów 2010. 
W objęciach Wielkiego Brata. Sowieci w Polsce 1944-1993, red. K. Rokicki, S. Stępień, Warszawa 2009.

Wæver O., Insecurity and identity unlimited, „Working Paper” (Kopenhaga) 1994, No. 14.

Wallis A., Socjologia wielkiego miasta, Warszawa 1967.

Wartości a polityka, red. D. Walczak-Duraj, Łódź 1999.

Wendt A., Anarchy is what states make of it. The social construction of power politics, „International Organization” 1992, vol. 46, No. 2.

Wendt A., Społeczna teoria stosunków międzynarodowych, Warszawa 2008.

White S., Feklyunina V., Identities and foreign policies in Russia, Ukraine and Belarus. The other Europes, Basingstoke-New York 2014.

Wierzejska M., Dziedziczak J., Obecność i postrzeganie Polski w mediach zagranicznych w roku 2017 (na podstawie doniesień z placówek), 2.09.2018 [dostęp: 26.11.2018], dostępny w internecie: <http://bi.gazeta.pl/im/2/23055/m23055222,MSZ.pdf>.

Williams M.C., Identity and the politics of security, „European Journal of International Relations" 1998, vol. 4, No. 2.

Wnuk-Lipiński E., Świat międzyepoki. Globalizacja, demokracja, państwo narodowe, Kraków 2004.

Wóycicki K., Nostalgia i polityka, Warszawa 2015.

Wstęp do teorii polityki zagranicznej państwa, red. R. Zięba, Toruń 2004.

Zehfuss M., Constructivism and identity. A dangerous liaison, „European Journal of International Relations" 2001, vol. 7, issue 3.

Zielonka J., Europa jako imperium. Nowe spojrzenie na Unię Europejska, Warszawa 2007. 